\title{
THE CONCEPTION AND RESPONSE OF MUSLIM COMMUNITY TO TAKAFUL SCHEMES: A CASE STUDY IN BAGAN SERAI, PERAK
}

\author{
By: \\ Idris Awang \& \\ Syukriyah Zakaria
}

\begin{abstract}
Al-tabarru' and al-mudārabah are the two fundamentals on which Islamic insurance or takâful is constructed. Since the late 1970's when it was first introduced the takaful industry has grown quite fast especially in countries of Muslim majority. Various products are offered both in the areas of family and general takaful, i.e. long and short terms insurance. The data in the current study are collected by means of a questionnaire administered on a sample of 100 respondents attempt to find out the relationship between understanding of the concept of takaful and participation in takaful schemes, gender, profession and income. The study concludes that there is no relationship between the understanding and the participation with the three variables but there is a positive relationship between understanding of takaful and participation in takaful schemes.
\end{abstract}

Based on the principles of al-tabarru' and al-mudärabah, literally means donation and profit sharing respectively, the Islamic-based insurance companies in Malaysia have developed numerous Islamic insurance or takaful products as alternatives to those offered by conventional insurance companies. These Islamic insurance products cover areas of 
Jurnal Fiq̨h: No. 2 (2005)

family, educational, professional, medical and vehicles as well as for investment purposes.

The history of takaful began in 1979 when an insurance company based on the Islamic principles was established in Sudan, The Sudan Islamic Insurance Company. This was followed by Saudi Arabia which set up the Arab Islamic Insurance Company in the same year. ${ }^{1}$ The $1980^{\prime} \mathrm{s}$ and $1990^{\prime}$ s saw the emergence of a number of Islamic insurance companies in Europe as well as in other Asian countries such as Luxembourg Islamic Takaful instituted under the Dār al-Māl al-Islāmì (DMI), London's Islamic Takaful Campany and in Malaysia, Syarikat Takaful Malaysia Berhad (STMB). In 1993, Brunei set up her own takaful company known as Takaful IBB Berhad and the following year saw Indonesia's first takaful company known as Syarikat Takaful Indonesia. ${ }^{2}$

When takaful companies continued to develop, the need for expansion of capital became the necessity, thus, encouraging the emergence of Islamic reinsurance campanies such as Al-Barakah Islamic Reinsurance Company (IIRCO) which was set up in Jeddah 1986. In North Africa, Sharikat Bait al-Tamwil was instituted in Tunisia to serve Islamic countries which were formerly under the French rule. ${ }^{3}$ These reinsurance companies are specially essential when smaller insurance companies could not compensate large claims because of disasters for instance.

In Malaysia, the initial idea of Islamic insurance came when the National Fatwa Committee in its June $15^{\text {th }} 1972$ session issued a fatwa that the conventional insurance as currently practiced is considered as fāsid mu'àmalah, that is,

1 Mohd. Fadzli Yusof (1996) Takaful: Sistem Insurans Islam. Kuala Lumpur: Utusan Publication \& Distributors Sdn. Bhd., p. 4.

2 Ibid.

3 Ibid. 
a transaction which contravenes certain Islamic principles. ${ }^{4}$ The fatwa prompted the setting up of a special consultative working committee to develop the idea of Islamic insurance and to advise the government on the matter. Subsequently, in 1984 Takaful Act was passed by the Malaysian Parliament under the existing Insurance Act (1963) ${ }^{5}$ giving way to the establishment of Syarikat Takaful Malaysia Bhd (STMB) which started to operate in 1985 and MNI Takaful in 1993, renamed Takaful Nasional Sdn Bhd (TNSB) in 2000. Other takaful companies followed suit especially in the first few years of 2000 such as Mayban Takaful and Takaful Ikhlas.

Takaful products offered by these takaful institutions can be summarized into family takaful and general takaful. The main difference between the two is the time span of coverage where family takaful has a long term coverage while general takaful has short term which is mostly a one year coverage. Family takaful includes education, hirepurchase, investment, health and medication which cover the risks in the cases of death, accident, critical illness, permanent incapability, and for educational and medical expenses. To name a few STMB's products or plans of this type are: hire-purchase, medical treatment, family group, health, and worker's fund and from the TNSB are Prima and Ehsan. There are a number of methods in which such products are implemented, for instance, $98 \%$ of the contribution or premium would be credited into participant's saving account (PSA), where transaction will be based on the principle of al-mudarabah and the remaining $2 \%$ will be credited into a special participant account (SPA) based on the principle of al-tabarru' . The

\footnotetext{
4 Azman bin Ismail \& Kamaruzzaman bin Abdullah (2000) Takaful: Teori dan Praktis. Kuala Lumpur: The Malaysian Insurance Institute, pp. 116-117.

Ibid.
} 
SPA will be generated by takaful company from where compensation will be made. ${ }^{6}$

The contract of general takaful is based on the principle of al-tabarru' and subjected to renewal, normally, on annual basis to cover the risk of the insured asset. Since general takaful is a short term contract based on al-tabarru' and covers a stipulated period, the excess of the fund, if any, will be refund to the participant. This is, of course, subjected to the condition where no claim of damage is made by the participant. ${ }^{7}$

This study is an attempt to understand the conception and response of Muslim communities towards takaful products particularly those offered by STMB and TNSB. Specifically, the study tries to answer these questions: How far does the community understand takaful schemes in general? Is there a relationship between the understanding of the schemes and gender, profession and incomes? How far is the acceptance of the schemes by the community? Is there a relationship between the acceptance and gender, profession and incomes? And finally, is there a relationship between the understanding and the acceptance of the schemes? Based on the questions, the following hypotheses are constructed: there is a relationship between the understanding of the schemes and gender, profession and incomes; there is a relationship between the acceptance of the schemes and gender, profession and incomes; and finally, there is a relationship between the understanding and the acceptance of the takaful schemes.

To answer the questions and to prove the hypotheses, a survey was conducted on a sample of 100 stratified respondents randomly selected from a district in Bagan Serai, Perak: 25 from public sector, 25 from agricultural

6 Dato' Mohd. Fadzli Yusof (undated) Introduction to Takaful. Kuala Lumpur: Utusan Publication \& Distributors Sdn. Bhd, pp. 27-40. 7 Ibid. 
sector, 25 from industrial sector and the final 25 were traders. The survey questionnaire consists of three sections: Section A on demography of the respondents, Section B on the understanding of the concept of takaful and Section $C$ on the response to the takaful schemes. In Section B, there are 20 Yes-Not sure-No questions to get responses regarding the understanding of takaful and the participation in takaful schemes.

The table below shows that the respondents are mostly from the age group of $20-45$ years $(73 \%) .74 \%$ are married and $63 \%$ are having monthly income of less than RM1000. Only $2 \%$ or 2 of the total 100 respondents is enjoying income of more than RM5000 per month. In other words, most of them are from the low income group.

Table 1: Distribution of respondents

\begin{tabular}{|l|l|c|}
\hline \multicolumn{2}{|c|}{ Respondent } & Frequency \\
\hline Gender & Male & 45 \\
& Female & 55 \\
\hline Age & $20-30$ & 50 \\
& $36-45$ & 23 \\
& $46-55$ & 19 \\
& $>55$ & 8 \\
\hline Status & Single & 26 \\
& Married & 74 \\
\hline Profession & Public & 25 \\
& Agricultural & 25 \\
& Trading & 25 \\
& Industrial & 25 \\
\hline & <M1000 & 63 \\
& RM1001-2000 & 22 \\
& RM2001-3000 & 10 \\
& RM3001-4000 & 2 \\
& RM4001-5000 & 1 \\
& $>$ RM5000 & 2 \\
\hline
\end{tabular}


Jurnal Fiqh: No. 2 (2005)

\section{CONCEPTION LEVEL OF TAKAFUL}

This section will attempt to look into the perception or understanding of the respondents towards the takaful scheme and product, the general concept of the takaful itself, the particular principles of al-tabarru' and almudārabah and the implementation of takaful.

In this paper takaful refers to the concept of takaful or Islamic insurance. Al-tabarru' (donation) and al-mudàrabah are the two basic principles or fundamentals on which the concept of takaful is constructed, while takaful scheme is referred to the scheme of takaful in general and takaful product refers to the various products or plans that are offered by takaful companies.

In an attempt to establish the level of knowledge of takaful and takaful schemes among the respondents, a section of the questionnaire used in the study with 20 questions were set aside for the purpose. Each correct answer was given a score 2 , not sure 1 and incorrect answer zero. The score distribution as follows are taken as a scale: less than 50 to mean low understanding, and 50-74 and more than 75 to mean as having moderate and high understanding respectively.

Table 2: Level of understanding of takaful schemes

\begin{tabular}{|l|l|c|}
\hline Level of understanding & Score & Frequency \\
\hline Low & $<50$ & - \\
\hline Moderate & $50-74$ & 60 \\
\hline High & $75-100$ & 40 \\
\hline Total & - & 100 respondents \\
\hline
\end{tabular}

The frequency distribution in the table 2 above shows that 40 or $40 \%$ of the respondents do have a good 
understanding of the schemes while $60 \%$ belong to the moderate group and no respondents perceive that they do not understand the scheme. This shows clearly that the respondents are conscious of the takaful schemes. They may know through advertisements or being informed by friends or next of kin.

Table 3: The understanding of the concept of takaful

\begin{tabular}{|l|c|c|c|c|}
\hline What is takaful? & Yes & Not sure & No & Total \\
\hline $\begin{array}{l}\text { Takaful is an Islamic } \\
\text { insurance }\end{array}$ & 91 & 8 & 1 & 100 \\
\hline $\begin{array}{l}\text { Takaful is an alternative } \\
\text { to the conventional takaful }\end{array}$ & 56 & 39 & 5 & 100 \\
\hline $\begin{array}{l}\text { Conceptually takaful is } \\
\text { different from the } \\
\text { conventional insurance }\end{array}$ & 19 & 43 & 38 & 100 \\
\hline $\begin{array}{l}\text { In takaful there are no } \\
\text { elements of gambling, } \\
\text { interest and doubt (gharar). }\end{array}$ & 81 & 16 & 3 & 100 \\
\hline $\begin{array}{l}\text { Takaful is based on the } \\
\text { concept of mutual support }\end{array}$ & 73 & 27 & - & 100 \\
\hline $\begin{array}{l}\text { Takaful is necessary for } \\
\text { risk coverage }\end{array}$ & 81 & 13 & 6 & 100 \\
\hline
\end{tabular}

Table 3 above attempts to depict the understanding of the concept of takaful itself. It indicates that as a whole, the respondents do have a good understanding of takaful, for instance, 91 believe that takaful is an Islamic insurance system, 81 agree that takaful is interest free and has no gambling elements, however, they cannot be certain of the difference between takaful and conventional insurance. 
Jurnal Fiqh: No. 2 (2005)

Table 4: Respondents' understanding of al-tabarru' (donation) as a principle of takaful

\begin{tabular}{|l|c|c|c|c|}
\hline What is al-tabarru'? & Yes & Not sure & No & Total \\
\hline $\begin{array}{l}\text { Tabarru' is a sum collected } \\
\text { to help one another }\end{array}$ & 52 & 48 & - & 100 \\
\hline $\begin{array}{l}\text { Tabarru' is the company's } \\
\text { money for donation }\end{array}$ & 20 & 63 & 17 & 100 \\
\hline $\begin{array}{l}\text { Tabarru' is contribution } \\
\text { collected before mishap while } \\
\text { donation after the mishap }\end{array}$ & 38 & 58 & 4 & 100 \\
\hline $\begin{array}{l}\text { The sum managed by insurance } \\
\text { company on behalf of } \\
\text { contributors / insurers }\end{array}$ & 28 & 68 & 4 & 100 \\
\hline
\end{tabular}

Figures in table 4 shows that despite of the fact that the respondents perceive themselves as to have good understanding of takaful as a general concept, they do not really understand the principle of tabarru' which is one of the bases of takaful itself. Most of the responses are in the category of 'note sure'. Though, 52 say that al-tabarru' is the sum collected to help one another, they are quite doubtful about what it is. Their perception probably is based on what they have been told by takaful agents.

Compared to al-tabarru', the figures in the table 5 below indicates that al-mudarabah is fairly understood by the respondents. 61 or $61 \%$ of the respondents have given a right response to the meaning of the concept and 52 could correctly say how the concept is applied, that is, based on the agreement between the participant and the takaful company. 
The Conception and Response to Takaful Schemes: A Case Study

Table 5: Respondents' understanding of al-mudārabah (profit sharing) as a basis in takaful

\begin{tabular}{|l|c|c|c|c|}
\hline What is al-mudärabah? & Yes & Not sure & No & Total \\
\hline The concept of profit sharing & 61 & 37 & 2 & 100 \\
\hline $\begin{array}{l}\text { The sharing of profit based on } \\
\text { agreement }\end{array}$ & 52 & 42 & 6 & 100 \\
\hline \begin{tabular}{l} 
The amount of profit gained \\
\hline
\end{tabular} & 36 & 59 & 5 & 100 \\
\hline
\end{tabular}

Form the figures in tables 3,4 and 5 above we could conclude that the respondents do have some knowledge about takaful and table 2 indicates they too know about the takaful schemes. Table 6 below tries to answer whether or not they understand how the schemes are implemented.

Table 6: Respondents' understanding of the implementation of takaful schemes

\begin{tabular}{|l|c|c|c|c|}
\hline Implementation of takaful schemes & Yes & Not sure & No & Total \\
\hline $\begin{array}{l}\text { Contribution separated into } \\
\text { tabarru' and personal account }\end{array}$ & 25 & 73 & 2 & 100 \\
\hline $\begin{array}{l}\text { Benefit to be paid from the } \\
\text { tabarru' account }\end{array}$ & 27 & 70 & 3 & 100 \\
\hline $\begin{array}{l}\text { Compensation is based on the } \\
\text { chosen plan }\end{array}$ & 48 & 47 & 5 & 100 \\
\hline $\begin{array}{l}\text { Compensation differs according } \\
\text { to value insured }\end{array}$ & 66 & 33 & 1 & 100 \\
\hline
\end{tabular}

Table 6 above shows that the method of the implementation of takaful schemes is not well understood by the respondents. They seem to pay attention more to the compensation aspect, while their knowledge in the technical aspects can be considered very low. Only 25\% know that participant's contribution is separated into tabarru' account and personal account and compensation 
Jurnal Fiqh: No. 2 (2005)

will be deducted from the pool of tabarru' accounts. The personal account will act as a saving account of the participant.

Table 7: Respondents' understanding of the operation of takaful products

\begin{tabular}{|l|c|c|c|c|}
\hline Takaful product & Yes & Not sure & No & Total \\
\hline Participation is open to everyone & 72 & 21 & 7 & 100 \\
\hline $\begin{array}{l}\text { Risk is not a condition for the with- } \\
\text { drawal from the saving account }\end{array}$ & 42 & 45 & 13 & 100 \\
\hline $\begin{array}{l}\text { Tabarru' account is not the right } \\
\text { of individual participant }\end{array}$ & 24 & 64 & 12 & 100 \\
\hline
\end{tabular}

Table 7 above shows the respondents' understanding of the operation of the takaful products. The figures seem to agree with their understanding of the implementation of takaful schemes except in terms of open participation, that is, anyone can participate in schemes, Muslims or nonMuslims. Their knowledge of the tabarru' account is very low.

Relationship between understanding takaful and gender, profession and income

Table 8: Respondents' understanding of takaful and gender

\begin{tabular}{|l|c|c|c|}
\hline \multirow{2}{*}{ Gender } & \multicolumn{2}{|c|}{ Perception of self understanding } & \multirow{2}{*}{ Total } \\
\cline { 2 - 4 } & Moderate & High & T5(45\%) \\
\hline Male & $29(64 \%)$ & $16(36 \%)$ & $55(55 \%)$ \\
\hline Female & $31(56 \%)$ & $14(44 \%)$ & 100 \\
\hline Total & $60(60 \%)$ & $40(40 \%)$ & \\
\hline
\end{tabular}


The Conception and Response to Takaful Schemes: A Case Study

Table 9: Relationship between understanding takaful and gender

\begin{tabular}{|l|c|c|c|l|}
\hline & $\begin{array}{c}\text { Chi square } \\
\text { value }\end{array}$ & $\begin{array}{c}\text { Chi square } \\
\text { critical value }\end{array}$ & $\begin{array}{c}\text { Degree of } \\
\text { freedom }\end{array}$ & Result \\
\hline Chi square & 3.36 & 3.84 & 1 & $\begin{array}{l}\text { Reject Ha, } \\
\text { accept Ho }\end{array}$ \\
\hline
\end{tabular}

$P=0.05$

The figures in table 8 above, besides showing that as a whole more respondents having a moderate understanding of takaful, seem to suggest that more women tend to understand takaful (44\%) compared to men (36\%). Statistically, is there a relationship between gender and the understanding of takaful? Figures in table 9 show that Chi square critical value (3.84) is greater than Chi square value (3.36) at degree of freedom of 1 and probability at 0.05 . We can interpret that the hypothesis cannot stand and has to be rejected giving way to the acceptance of null hypothesis, thus, concluding that gender plays no significant relationship in the understanding of takaful.

Table 10: Respondents' understanding of takaful and profession

\begin{tabular}{|l|c|c|c|}
\hline \multirow{2}{*}{ Profession } & \multicolumn{2}{|l|}{ Perception of self understanding } & \multirow{2}{*}{ Total } \\
\cline { 2 - 3 } & Moderate & High & \\
\hline Public servant & $10(40 \%)$ & $15(16 \%)$ & $25(25 \%)$ \\
\hline Agricultural & $19(76 \%)$ & $6(24 \%)$ & $25(25 \%)$ \\
\hline Trade & $15(60 \%)$ & $10(40 \%)$ & $25(25 \%)$ \\
\hline Industrial & $16(64 \%)$ & $9(36 \%)$ & $25(25 \%)$ \\
\hline Total & $60(60 \%)$ & $40(40 \%)$ & 100 \\
\hline
\end{tabular}


Jurnal Fiqh: No. 2 (2005)

Table 11: Relationship between respondents' understanding and profession

\begin{tabular}{|l|c|c|c|c|}
\hline & $\begin{array}{c}\text { Chi square } \\
\text { value }\end{array}$ & $\begin{array}{c}\text { Chi square } \\
\text { critical value }\end{array}$ & $\begin{array}{c}\text { Degree } \\
\text { of freedom }\end{array}$ & Result \\
\hline Chi square & 6.98 & 7.81 & 3 & $\begin{array}{l}\text { Rejected H a, } \\
\text { accept H o }\end{array}$ \\
\hline
\end{tabular}

$\mathrm{P}=0.05$

The percentages in table 10 above show that for all types of the profession, understanding of the concept of takaful is at moderate level with agricultural type of profession having the highest percentage followed by industrial. But what about the relationship between the types of profession and the understanding? It is hypothesized that there is a relationship between types of profession and the understanding of takaful. The values in table 11, however, reject the hypothesis accepting the null hypothesis: there is no relationship between the two variables. At the degree of freedom 3 and probability 0.05 , the Chi square critical value is greater (7.81) compared to Chi square value (6.98).

Table 12: Respondents' understanding and their income

\begin{tabular}{|l|c|c|c|}
\hline \multirow{2}{*}{ Monthly income } & \multicolumn{2}{|c|}{ Perception of understanding } & \multirow{2}{*}{ Total } \\
\cline { 2 - 3 } & Moderate & High & \\
\hline <RM1000 & $38(60 \%)$ & $25(40 \%)$ & $63(63 \%)$ \\
\hline RM1001-2000 & $12(55 \%)$ & $10(45 \%)$ & $22(22 \%)$ \\
\hline RM2001-3000 & $7(70 \%)$ & $3(30 \%)$ & $10(10 \%)$ \\
\hline RM3001-4000 & $2(100 \%)$ & - & $2(2 \%)$ \\
\hline RM4001-5000 & - & $1(100 \%)$ & $1(1 \%)$ \\
\hline$>$ RM5000 & - & $2(100 \%)$ & $2(2 \%)$ \\
\hline Total & $60(60 \%)$ & $40(40 \%)$ & 100 \\
\hline
\end{tabular}


The Conception and Response to Takaful Schemes: A Case Study

Table 13: Relationship between income and the understanding of takaful

\begin{tabular}{|l|c|c|c|c|}
\hline & $\begin{array}{c}\text { Chi square } \\
\text { value }\end{array}$ & $\begin{array}{c}\text { Chi square } \\
\text { critical value }\end{array}$ & $\begin{array}{c}\text { Degree of } \\
\text { freedom }\end{array}$ & Result \\
\hline Chi square & 5.84 & 11.07 & 5 & $\begin{array}{l}\text { Reject } \mathrm{H} \mathrm{a} \\
\text { accept } \mathrm{H} \text { o }\end{array}$ \\
\hline
\end{tabular}

$P=0.05$

Table 12 gives a general picture concerning respondents understanding and their income. It is not surprising that the higher income category with monthly income of RM1000 plus which can be assumed to have a higher education to have a better understanding of takaful. Is it the truth of the picture? It is hypothesized that there is a relationship between income and the understanding of takaful. Table 13, however, gives a different answer. Chi square critical value is greater than Chi square value at the degree of freedom 5 with probability 0.05 and this indicates that there is no relationship between income and the understanding of takaful

Participation in takaful schemes and gender, profession and income

Table 14: Respondents' participation in takaful schemes and gender

\begin{tabular}{|l|c|c|c|}
\hline Gender & Participant & Non-participant & Total \\
\hline Male & $15(33 \%)$ & $30(67 \%)$ & $45(45 \%)$ \\
\hline Female & $18(33 \%)$ & $37(67 \%)$ & $55(55 \%)$ \\
\hline Total & $33(33 \%)$ & $67(67 \%)$ & 100 \\
\hline
\end{tabular}


Jurnal Fiqh: No. 2 (2005)

Table 15: Relationship between gender and participation in takaful schemes

\begin{tabular}{|l|c|c|c|c|}
\hline & $\begin{array}{c}\text { Chi square } \\
\text { value }\end{array}$ & $\begin{array}{c}\text { Chi square } \\
\text { critical value }\end{array}$ & $\begin{array}{c}\text { Degree of } \\
\text { freedom }\end{array}$ & Result \\
\hline Chi square & 0.004 & 3.84 & 1 & $\begin{array}{c}\text { Reject H a, } \\
\text { accept H o }\end{array}$ \\
\hline
\end{tabular}

$\mathrm{P}=0.05$

Table 14 indicates that of the 100 respondents only $33 \%$ are participants in takaful schemes, $67 \%$ are nonparticipants. The same percentage applies to male and female participants. In trying to prove the hypothesis that there is a relationship between gender and participation in takaful schemes, table 15 proves otherwise, that is rejecting the hypothesis and accepting the null hypthesis at degree of freedom 1 and probability at 0.05 giving greater Chi square critical value (3.84) compared to the Chi square value $(0.004)$

Table 16: Respondents' participation in takaful schemes and profession

\begin{tabular}{|l|c|c|c|}
\hline Type of Profession & Participant & Non-participant & Total \\
\hline Public servant & $13(52 \%)$ & $12(48 \%)$ & $25(25 \%)$ \\
\hline Agricultural & $6(24 \%)$ & $19(76 \%)$ & $25(25 \%)$ \\
\hline Trade & $9(36 \%)$ & $16(64 \%)$ & $25(25 \%)$ \\
\hline Industrial & $5(20 \%)$ & $20(80 \%)$ & $25(25 \%)$ \\
\hline Total & $33(33 \%)$ & $67(67 \%)$ & 100 \\
\hline
\end{tabular}


Table 17: Relationship between respondents' participation and type of profession

\begin{tabular}{|l|c|c|c|c|}
\hline & $\begin{array}{c}\text { Chi square } \\
\text { value }\end{array}$ & $\begin{array}{c}\text { Chi square } \\
\text { critical value }\end{array}$ & $\begin{array}{c}\text { Degree of } \\
\text { freedom }\end{array}$ & Result \\
\hline Chi square & 6.98 & 7.81 & 3 & $\begin{array}{c}\text { Reject H a, } \\
\text { accept H o }\end{array}$ \\
\hline $\mathrm{P}=0.05$ & & &
\end{tabular}

In terms of participation, public servants make up the most among the participants. The involvement in takaful schemes is relatively lower. among respondents in other types of profession. However, table 17 proves that the two variables, that is, participation and profession, have no relationship. The hypothesis that there is relationship between participation in takaful schemes and types of profession cannot be accepted. The critical value is higher (7.81) than Chi square value (6.98) at degree of freedom 3 and probability 0.05 .

Table 18: Respondents' participation in takaful schemes and income

\begin{tabular}{|l|c|c|c|}
\hline Monthly income & Participant & Non-participant & Total \\
\hline <RM1000 & $17(27 \%)$ & $46(73 \%)$ & $63(63 \%)$ \\
\hline RM1001-2000 & $10(45 \%)$ & $12(55 \%)$ & $22(22 \%)$ \\
\hline RM2001-3000 & $5(50 \%)$ & $5(50 \%)$ & $10(10 \%)$ \\
\hline RM3001-4000 & $1(50 \%)$ & $1(50 \%)$ & $2(2 \%)$ \\
\hline RM4001-5000 & - & $1(100 \%)$ & $1(1 \%)$ \\
\hline >R $\$$ M5000 & - & $2(100 \%)$ & $2(2 \%)$ \\
\hline Total & $33(33 \%)$ & $67(67 \%)$ & 100 \\
\hline
\end{tabular}


Jurnal Fiqh: No. 2 (2005)

Table 19: Relationship between respondents' participation and monthly income

\begin{tabular}{|c|c|c|c|c|}
\hline & $\begin{array}{c}\text { Chi square } \\
\text { value }\end{array}$ & $\begin{array}{c}\text { Chi square } \\
\text { critical value }\end{array}$ & $\begin{array}{c}\text { Degree of } \\
\text { freedom }\end{array}$ & Result \\
\hline Chi square & 5.59 & 11.07 & 5 & $\begin{array}{l}\text { Reject H a, } \\
\text { accept H o }\end{array}$ \\
\hline
\end{tabular}

$\mathrm{P}=0.05$

Participation among the lower income group especially those who are in the RM1000-RM3000 range is low. Those having less than RM1000 may not be able to pay the premium and those whose income is above RM4000 would probably prefer to participate in the conventional insurance. In terms of relationship, table 19 indicates that what is hypothesized as there is a relationship between the two variables, i.e., income and participation in takaful schemes, proves to be untrue and the null hypothesis is accepted.

Table 20: Understanding takaful and participation in takaful schemes

\begin{tabular}{|l|c|c|c|}
\hline $\begin{array}{l}\text { Level (score) of } \\
\text { understanding }\end{array}$ & Participant & Non-participant & Total \\
\hline High & $19(57 \%)$ & $21(31 \%)$ & $40(40 \%)$ \\
\hline Moderate & $14(43 \%)$ & $46(69 \%)$ & $60(60 \%)$ \\
\hline Low & - & - & - \\
\hline Total & $33(33 \%)$ & $67(67 \%)$ & 100 \\
\hline
\end{tabular}


Table 21: Relationship between understanding takaful and participation in takaful schemes

\begin{tabular}{|l|c|c|c|c|}
\hline & $\begin{array}{c}\text { Chi square } \\
\text { value }\end{array}$ & $\begin{array}{c}\text { Chi square } \\
\text { critical value }\end{array}$ & $\begin{array}{c}\text { Degree of } \\
\text { freedom }\end{array}$ & Result \\
\hline Chi square & 6.31 & 3.84 & 1 & $\begin{array}{c}\text { Reject H o, } \\
\text { Accept H a }\end{array}$ \\
\hline
\end{tabular}

$P=0.05$

Respondents perceive themselves as having good understanding of takaful. Though participation is very low, i.e. only $33 \%$, among the participants the percentage of those having better understanding is higher compared to those who have moderate understanding. Table 21 proves the hypothesis which says that there is relationship between understanding of takaful and participation in takaful schemes - Chi square value is higher (6.31) than Chi square critical value (3.84) at degree of freedom 1 and probability 0.05 .

From the study we can conclude that there is no relationship between understanding the concept of takaful and gender, profession or income. The data also indicate that there is no relationship between participation in takaful schemes and gender, profession or income. However, there is a positive relationship between understanding takaful and participation in takaful schemes. This implies that it is imperative for takaful promoters to take aggressive measures to make people understand takaful and to promote takaful schemes. Takaful promoters should work together in a consortium to educate and to make the society understand in the concept of takaful and 
Jurnal Fiqh: No. 2 (2005)

the operation of takaful schemes. Individually, they too have to be strategically more aggressive to promote their takaful products. 